\title{
Asesmen Potential Review pada Pegawai Pelabuhan PT.X (Umpan balik: Pengembangan Kompetensi Melalui Konseling)
}

\author{
Andi Muhammad Aditya ${ }^{1}$, Nur Pratiwi Noviati ${ }^{2}$ \\ Universitas Bosowa, Indonesia ${ }^{1}$ \\ Aditya.muhammad@Universitasbosowa.ac.id*
}

\section{Article Information:}

Received April 17, 2020

Revised June 4, 2020

Accepted June 16, 2020

Keywords: Potential Review, Human Resources Development, Counseling

\section{Abstract}

PT.X is a service business-oriented company in Indonesia, namely in the port service sector. In order to increase HR competency, PT.X regularly conducts potential reviews on several classes of positions including senior analysts, senior assistant managers, and senior managers. The research objective was to determine the actual condition of the employees' competencies. Data collection methods used were psychological tests, observation, interviews, and LGD. Data analysis used qualitative and quantitative descriptive analysis. The subject in this study was a 44 year old woman who was an employee at PT. $X$ in the supporting facilities subdivision (FP) who has a structural position as Assistant Senior Manager (ASM). The results showed that from the entire series of assessments carried out to Ms.Y, it showed that there were 10 competencies that met the standards, 3 competencies in the category above the standard, and 1 competency below the standard. This means that generally Ms.Y meets the standards of her current position. The conclusion from this potential review assessment shows that Ms. Y meets the competency standards in her position as ASM in the supporting facilities subdivision, however, further development is needed regarding substandard competencies using counseling training so that Ms.Y can implement it to subordinates.

\section{PENDAHULUAN}

PT.X merupakan perusahaan dengan orientasi bisnis pelayanan di Indonesia yaitu pada bidang port service. PT.X merupakan sebuah perusahaan yang memiliki beberapa cabang wilayah di seluruh Indonesia dengan memberikan penomoran wilayah 1, 2, dan seterusnya. PT. X yang dibahas saat ini adalah salah satu cabang wilayah terbesar diantara wilayah lainnya karena memiliki jangkauan area bisnis di seluruh Kawasan Timur Indonesia (KTI). Tentu dengan orientasi bisnis pada pelayanan komersial maupun non-komersial sangat membutuhkan infrastruktur untuk memudahkan seluruh proses bisnis yang dilakukan. Dalam PT.X terdapat sebuah divisi yang menangani hal tersebut yaitu pada divisi fasilitas dan peralatan, secara umum untuk menyediakan segala kebutuhan fisik yang diperlukan oleh perusahaan. Pada divisi fasilitas dan peralatan terbagi atas beberapa sub divisi, salah satunya ialah sub divisi fasilitas penunjang.

Sub divisi fasilitas penunjang memiliki peranan yang cukup penting pada perusahaan yaitu, secara umum berkaitan dengan pekerjaan-pekerjaan yang bersifat investasi dan pemeliharaan kantor pusat serta seluruh cabang yang berkaitan dengan bangunan darat, bangunan darat yang dimaksud pada sub divisi ini yaitu terminal penumpang dan kantor pada PT. X, termasuk di dalamnya seluruh sub cabang di wilayah Kawasan Timur Indonesia (KTI). Proses implementasi pada pekerjaan di sub divisi. fasilitas penunjang ini yaitu mulai dari perencanaan terkait dengan detect engginering design (DED) hingga pelaksanaan fisiknya.

Selain dengan tugas-tugas pokok pada sub divisi tersebut, melihat persaingan yang 
semakin ketat pada bidang bisnis yang sama pada PT.X yang di dukung oleh UU no.17 tahun 2008 yang secara esensi memberikan ruang yang semakin bebas pada pihak swasta lainnya untuk menggeluti bidang bisnis yang sama dengan PT.X maka akan cukup berdampak pada pendapatan, sehingga jika dari segi fasilitas PT.X kurang, maka tentu akan tertinggal oleh pihak-pihak swasta yang memiliki kesiapan fasilitas yang lebih baik dari perusahaan, apalagi jika swasta asing yang rata-rata memiliki investasi modal yang tinggi.

Untuk menghadapi berbagai kemungkinan persaingan bisnis serta melakukan perencanaan fasilitas dan peralatan secara tepat dalam jangka panjang, maka penting untuk mempertimbangkan Sumber Daya Manusia (SDM) unggul dalam menempati posisi struktural yang berfungsi untuk merencanakan, memutuskan, dan melaksanakan berbagai program demi keberlangsungan perusahaan, apalagi PT.X merupakan bisnis yang bergerak pada bidang pelayanan, sehingga ujung tombaknya adalah pada fasilitas infrastruktur dan suprastruktur.

Dalam rangka peningkatan kompetensi SDM maka PT.X secara berkala melakukan potential review pada beberapa kelas jabatan diantaranya adalah analis senior, asisten senior manajer, dan senior manajer. Pada kasus individu ini maka subjek merupakan pejabat struktural pada direktorat fasilitas peralatan dengan posisi Asisten Senior Manaje (ASM) fasilitas penunjang sehingga termasuk pada aturan perusahaan yang mengharuskan dilakukannya potential review pada subjek. Potential review menurut Munandar (2003) adalah sebuah proses deskripsi keterampilan dan kemampuan individu yang berisikan kelemahan dan kelebihan yang dapat dikembangkan. Pentingnya potential review pada kasus ini adalah untuk mengetahui kondisi aktual kompetensi yang dimiliki pegawai untuk menduduki posisi Asisten Senior Manajer (ASM) fasilitas penunjang pada divisi fasilitas dan peralatan, konteks pekerjaan untuk posisi ini sangat berkaitan dengan optimalisasi dari pelayanan kepada pengguna jasa.

Potential review menurut Munandar (2003) adalah sebuah proses deskripsi keterampilan dan kemampuan individu yang berisikan kelemahan dan kelebihan yang dapat dikembangkan. Terdapat beberapa kompetensi yang dibutuhkan di divisi Fasilitas dan Peralatan (FP) pada PT.X khususnya berada pada posisi Asisten Senior Manajer (ASM) fasilitas penunjang. Pada dasarnya di PT.X membagi kompetensi kedalam tiga cakupun yang luas yaitu (1) kompetensi peran yaitu untuk struktural dan non struktural, (2) kompetensi fungsional yaitu hard kompetensi dan soft kompetensi, (3) kompetensi dasar adalah keahlian dasar yang harus dimiliki oleh semua pegawai, dan (4) kompetensi inti, yaitu kompetensi yang wajib dimiliki oleh pegawai pada posisi tersebut dengan standar yang telah ditentukan.

Subjek dalam penelitian ini merupakan seorang pegawai dengan jabatan struktural sehingga membutuhkan kompetensi peran struktural yang mesti dimiliki oleh semua para ASM di lingkungan PT.X khususnya pada bidang fasilitas penunjang yang sesuai dengan tugas dan fungsinya, terdapat 3 kompetensi yaitu kompetensi change leadership (CL) dan kompetensi strategic thingking (ST) untuk mempersiapkan para bawahannya megikuti atau menjalankan seluruh kemungkinan perubahan kebijakan atau strategi bisnis dari perusahaan. Kemudian kompetensi developing others (DEV) merupakan kompetensi yang menuntut agar posisi ASM atau pejabat struktural dapat mengembangkan bawahannya secara mandiri dengan pendekatannya masing-masing.

Selanjutnya pada kompetensi fungsional, terdapat dua pembagian kategori kompetensi yaitu hard dan soft kompetensi. Pada hard kompetensi merupakan keahlian pegawai terkait dengan operasional pelabuhan dan sangat berpengaruh pada proses bisnis perushaan, pada kompetensi ini terdapat kompetensi port planning operation (PPO) untuk melakukan dan melaksanakan perencanaan pelabuhan jangka pendek maupun panjang dan kompetensi port development (PD) untuk melakukan pengembangan pelabuhan baik dari sisi infrastruktur maupun suprastruktur kepelabuhanan. Kemudian, pada soft skill maka terdapat kompetensi information seeking (IS) yaitu agar pegawai pada posisi tersebut mampu mengumpulkan informasi yang dibutuhkan dari berbagai sumber dengan berbagai metode sehingga dapat menunjang segala keputusan dan perencanaan maupun pelaksanaan operasional pelabuhan. 
Pada kompetensi keahlian dasar yang harus dimiliki pada posisi ASM maka terdapat 4 kompetensi yaitu problem solving and decision making (PSDM), computer literacy (CL), communication (COM), dan english communication (EC). Keempat kompetensi tersebut dibutuhkan sebagai keahlian yang sangat mendasar di hampir seluruh jabatan baik struktural maupun non struktural pada PT.X karena merupakan kemampuan yang dapat diaplikasikan sehari-hari dalam menjalankan proses bisnis perusahaan, selain itu kompetensi tersebut juga sangat erat kaitannya dengan rutinitas pada kantor pusat di PT.X yang mengurusi banyak cabang unit diseluruh Kawasan Timur Indonesia.

Adapun kompetensi inti yang diwajibkan kepada seluruh pegawai baik struktural maupun non struktural di berbagai level adalah terdiri dari 4 yaitu achievement orientation $(\mathrm{ACH})$, costumer service orientation (CSO), Intrapreneurship (INTRA), dan integrity (ING). Keempat kompetensi ini menggambarkan tentang komitmen para pegawai kepada perusahaan dengan orientasi prestasi kerja mereka, kemudian kemampuan pegawai dalam melakukan berbagai pelayanan karena berhubung bidang bisnis PT.X merupakan di bidang pelayanan di pelabuhan sehingga erat kaitannya dengan para pengguna jasa. Adapun yang berhubungan dengan kompetensi ini yaitu kemampuan pegawai dalam melaksanakan seluruh program dan keputusan serta perencana perusahaan jangka panjang dan pendek dengan memanfaatkan berbagai potensi perusahaan dan berlandas serta sesuai pada aturan dan kebijakan yang telah ditetapkan perusahaan sehingga menghindari potensi sejumlah kesalahan di lapangan yang bertentangan dengan perusahaan. Untuk mengetahui kondisi aktual kompetensi yang dimiliki oleh pegawai dengan posisi Asisten Senior Manajer (ASM) pada subdivisi fasilitas penunjang dibawah naungan divisi fasilitas dan peralatan PT.X

\section{METODE PENELITIAN}

Metode yang digunakan dalam penelitian asesmen potential review ini terbagi menjadi dua yaitu metode tes dan metode non tes. Dalam metode tes menggunakan alat tes psikologi yang terdiri TIKI, Papi Kostick, DAP, BAUM, Wateg, dan Kraeplin. Untuk metode non tes dilakukan dengan 3 cara yaitu observasi, wawancara, dan leaderless group discussion (LGD).

Subjek dalam penelitian ini adalah perempuan berusia 44 tahun, merupakan seorang pegawai di PT. X pada subdivisi fasilitas penunjang (FP) yang memiliki jabatan struktural sebagai Asisten Senior Manajer (ASM). Deskripsi umum jabatannya sebagai ASM pada subdivisi fasilitas penunjang adalah (1) Membuat perencanaan pemeliharaan fasilitas (terminal dan kantor), (2) Melakukan perhitungan dana internal investasi, (3) Melaksanakan program yang direncanakan, (4) Melakukan pemantauan secara berkala, (5) Melakukan koordinasi pada pihak-pihak yang berkaitan dengan fasilitas penunjang demi percepatan penuntasan program kerja tahunan maupun bulanan, (6) Melakukan pelaporan kepada atasan.

\section{Metode Tes}

Tes psikologi merupakan sebuah alat pengukuran atau teknik pengukuran untuk mendapatkan kesimpulan terkait sifat-sifat manusia, karakteristik atau untuk memprediksi masa yang akan datang. Untuk membuat kesimpulan dalam hasil tes psikologi maka diperlukan bukti-bukti yang didapat dalam hasil tes (Miller dan Lovler, 2016). Dalam metode tes ini akan menggunakan sejumlah alat tes psikologi yaitu; TIKI, Papi Kostick, DAP, BAUM, Wateg, dan Kraeplin. Berikut adalah uraian informasi alat tes psikologi yang digunakan dalam potential review penelitian ini: Tes intelegensi yang digunakan dalam penelitian ini adalah Tes Inteligensi Kolektif Indonesia (TIKI) dengan kategori TIKI tinggi. TIKI digunakan sebagai alat untuk mengungkap intelegensi subjek, tes yang disusun di Indonesia ini merupakan kerjasama antara ahli Indonesia dan Belanda, bertujuan untuk mengungkap inteligensi dengan standar Indonesia. Tes ini dapat diberikan secara individual dan kelompok. Sub tes TIKI tinggi (berhitung angka, gabungan bagian, hubungan kata, abstraksi non verbal, deret angka, meneliti, membentuk benda, eksklusi kata, bayangan cermin, analogi kata, bentuk tersembunyi, pembentukan kata) (Nuraeni, 2012).

Tes kepribadian yang digunakan dalam potential review adalah PAPI Kostic, tes grafiss 
(DAP dan BAUM), wartegg. Ketiga alat tes tersebut digunakan agar dapat mengungkap gambaran relasi sosial, pengelolaan emosi dan dorongan berprestasi yang dimiliki oleh subjek dan bagaimana perilaku subjek ketika berada dalam sebuah lingkungan. Berikut adalah penjelasan informasi tes kepribadian digunakan, yaitu (1) PAPI Kostic dikenal sebagai preference and perception inventory. Tes ini merupakan salah satu tes kepribadian yang tercermin dalam tingkah laku yang didasarkan pada kategorisasi. PAPI mengukur roles dan need individu dalam kaitannya dengan situasi kerja (Rumiani, dkk; 2014). PAPI Kostic digunakan pada penelitian ini karena dapat mengungkap sesuatu yang dipersepsikan karyawan terhadap situasi kerja dan hal-hal yang disukai untuk bertindak dalam suatu cara tertentu sehingga mampu mengungkap kecenderungan karyawan dalam situasi bekerja nanti. Terdapat 20 aspek kepribadian yang dikelompokkan menjadi 7 bidang yaitu kepemimpinan (leadership), arah kerja (work direction), aktivitas kerja (activity), relasi sosial (social nature), gaya bekerja (work style), sifat tempramen (temprament) dan posisi atasan-bawahan (followership). (2) Tes wartegg merupakan tes kepribadian yang menggunakan rangsangan gambar. Wartegg digunakan untuk mengeksplorasi struktur kepribadian subjek yang terdiri dari motivasi, kemampuan sosial, emosi dan pemecahan masalah. Terdapat 8 kotak gambar, dimana masing-masing kotak diberi sebuah elemen grafis kecil dimana subjek diminta untuk mengembangkan elemen grafis tersebut dengan cara subjek sendiri. (3) Tes grafis yang akan digunakan dalam potential review adalah BAUM dan DAP (draw a person). Tes grafis merupakan tes proyektif. Tes grafis digunakan dalam penelitian ini bertujuan untuk mengungkap kepribadian subjek yang berhubungan dengan relasi sosial, motivasi berprestasi dan pengendalian diri subjek yang nantinya digunakan untuk memprediksi perilaku subjek ketika bekerja.

Tes sikap kerja yang digunakan dalam potential review pegawai ini adalah kraeplin. Tes kraeplin pada penelitian ini digunakan untuk mengukur maximum perfomance seseorang terutama dalam situasi yang menekan sehingga dapat menjadi dasar untuk melihat kecenderungan subjek. Aspek-aspek yang diukur dalam tes ini adalah kecepatan kerja, ketelitian kerja, keajegan kerja dan ketahan kerja (Rumiani, dkk; 2014). Aspek yang ingin diungkap dalam potential review adalah ketelitian kerja, kecepatan kerja dalam memberikan pelayanan dan menangani keluhan dari pelanggan.

\section{Metode Non Tes}

Dalam metode non tes menggunakan tiga metode yaitu wawancara, observasi, dan leaderless group discussion. Wawancara individual yang dilakukan untuk potential review adalah behavioral event interview (BEI). Behavioral event interview menurut Boyatziz (1982) adalah sebuah bentuk wawancara insiden kritis dimana responden diminta untuk menceritakan insiden efektif dan tidak efektif dalam bekerja. Teknik BEI digunakan dalam penelitian ini karena dianggap metode yang paling valid dalam metode asessmen karena mampu memperoleh sampel perilaku seseorang yang sebenarnya dalam melakukan pekerjaan. BEI juga mampu menunjukkan kompetensi dan level kompetensi (Boyatziz, 1982). Selain mendapatkan gambaran terkait kompetensi, BEI juga mampu menjadi prediktor terkait kesuksesan pekerjaan di masa depan (Boulter, Dalziel dan Hill, 2003).

Observasi. Observasi adalah metode pengumpulan data langsung dari lapangan. Data yang di observasi dapat berupa gambaran tentang sikap, kelakuan, perilaku, tindakan, keseluruhan interaksi antar manusia. Data observasi dapat berupa sebuah interaksi dalam suatu organisasi atau pengalaman anggota dalam berorganisasi. Observasi dimulai dengan mengidentifikasi tempat dan membuat pemetaan agar memperoleh gambaran umum tentang sasaran penelitian (Raco, 2010). Observasi yang dilakukan pada penelitian ini dilakukan pada saat proses wawancara berlangsung. Dimana peneliti melakukan obervasi pada saat sebelum melakukan wawancara, proses selama wawancara, dan pasca melakukan wawancara. Peneliti mengobservasi subjek hampir selama sehari penuh.

Leaderless Group Discussion. Dalam LGD pada asesmen ini akan mengangkat sebuah kasus untuk memberikan ruang kepada para peserta untuk menganalisis gambaran rinci 
sebuah tindakan tertentu untuk mengenali perilaku yang tepat atau tidak tepat serta membuat rekomendasi mengenai apa yang seharusnya dilakukan atau apa yang harus dilakukan. Kasus bisa digunakan untuk menunjukkan bagaimana masalah atau peristiwa yang sama dapat berbeda bagi orang yang memiliki nilai, minat, dan asumsi yang berbeda. Selain itu, kasus juga dapat digunakan untuk menilai kemampuan seseorang menganalisis alasan atas masalah hubungan manusia dan mengenali cara efektif menangani situasi hubungan antar pribadi (Yukl, 2015).

\section{Profil Kompetensi}

Berikut dibawah ini menggambarkan secara spesifik daftar kompetensi serta level kompetensi pada jabatan struktural ASM di bidang fasilitas penunjang PT.X.

Tabel 1. Profil kompetensi ASM Fasilitas dan Penunjang

\begin{tabular}{|c|c|c|c|c|c|c|c|}
\hline \multirow{2}{*}{ No. } & \multirow{2}{*}{ Aspek } & \multirow{2}{*}{ Uraian } & \multicolumn{5}{|c|}{ Level } \\
\hline & & & 1 & 2 & 3 & 4 & 5 \\
\hline 1. & $\begin{array}{l}\text { Strategic } \\
\text { Thingking }\end{array}$ & $\begin{array}{l}\text { Kemampuan untuk mengembangkan berbagai aspek } \\
\text { strategis dalam merumuskan dan mengambil tindakan } \\
\text { strategis di unit kerja yang dipimpinnya bagi } \\
\text { kebutuhan jangka pendek maupun jangka panjang }\end{array}$ & & & & & \\
\hline 2. & $\begin{array}{l}\text { Problem Solving } \\
\text { and Decision } \\
\text { Making }\end{array}$ & $\begin{array}{l}\text { Kemampuan untuk menganalisa dan memilah } \\
\text { masalah/situasi/ peristiwa dengan menggunakan } \\
\text { informasi dan pendekatan tertentu untuk mengambil } \\
\text { keputusan/ penyelesaian masalah }\end{array}$ & & & & & \\
\hline 3. & $\begin{array}{l}\text { Customer } \\
\text { Service } \\
\text { Orientation }\end{array}$ & $\begin{array}{l}\text { Keinginan untuk membantu atau melayani pelanggan / } \\
\text { orang lain. Pelanggan adalah pelanggan yang } \\
\text { sesungguhnya atau rekan pemakai hasil kerja kita }\end{array}$ & & & & & \\
\hline 4. & $\begin{array}{l}\text { Change } \\
\text { Leadership }\end{array}$ & $\begin{array}{l}\text { Kemampuan untuk memberikan dorongan } \\
\text { mempengaruhi, serta melibatkan bawahan dalam } \\
\text { melakukan perubahan organisasi untuk mencapai } \\
\text { sasaran jangka pendek maupun jangka panjang }\end{array}$ & & & & & \\
\hline 5. & Intrapreneurship & $\begin{array}{l}\text { Kemampuan untuk dapat mengidentifikasi tanggung } \\
\text { jawab/peluang usaha baru berdasarkan sumber daya } \\
\text { yang dimiliki perusahaan untuk meningkatkan } \\
\text { performa perusahaan }\end{array}$ & & & & & \\
\hline 6. & $\begin{array}{l}\text { Information } \\
\text { Seeking }\end{array}$ & $\begin{array}{l}\text { Kemampuan untuk menggali informasi dan } \\
\text { mengetahui suatu hal secara lebih mendalam dari } \\
\text { berbagai sumber baik yang terkait langsung maupun } \\
\text { tidak langsung }\end{array}$ & & & & & \\
\hline 7. & $\begin{array}{l}\text { Port Planning } \\
\text { and Operation }\end{array}$ & $\begin{array}{llrr}\text { Kemampuan } & \text { untuk } & \text { melakukan } & \text { perencanaan } \\
\text { pengembangan fasilitas pelabuhan dan fasilitas } & \text { dan } \\
\text { penunjang mencakup kawasan industri penunjang }\end{array}$ & & & & & \\
\hline 8. & $\begin{array}{l}\text { Port } \\
\text { Development }\end{array}$ & $\begin{array}{lcc}\text { Memiliki keahlian dalam perencanaan } & \text { dan } \\
\text { pengembangan peralatan dan fasilitas pelabuahan } & \end{array}$ & & & & & \\
\hline 9. & $\begin{array}{l}\text { Developing } \\
\text { Other }\end{array}$ & $\begin{array}{l}\text { Kemampuan untuk mengembangkan bawahan agar } \\
\text { dapat memiliki kompetensi sesuai dengan tuntunan } \\
\text { jabatan (standar kompetensi) atau mengembangkan } \\
\text { bawahan dengan menempatkan bawahan pada } \\
\text { pekerjaan yang sesuai dengan kompetensinya }\end{array}$ & & & & & \\
\hline 10. & $\begin{array}{l}\text { Computer } \\
\text { Literacy }\end{array}$ & $\begin{array}{l}\text { Kemampuan untuk menggunakan program komputer } \\
\text { dalam pekerjaan }\end{array}$ & & & & & \\
\hline 11. & Communication & $\begin{array}{l}\text { Kemampuan untuk menerima dan memahami } \\
\text { informasi dari orang lain, menyampaikan sesuatu } \\
\text { maksud atau informasi secara jelas, menggunakan } \\
\text { berbagai saran komunikasi, berbicara di depan umum } \\
\text { dan melakukan negosiasi }\end{array}$ & & & & & \\
\hline
\end{tabular}




\begin{tabular}{|c|l|l|l|l|l|l|}
\hline 12. & $\begin{array}{l}\text { English } \\
\text { Communication }\end{array}$ & $\begin{array}{l}\text { Kemampuan untuk memahami dan menyampaikan } \\
\text { informasi dalam Bahasa Inggris, baik secara lisan } \\
\text { maupun tulisan }\end{array}$ & & & & \\
\hline 13. & $\begin{array}{l}\text { Achievement } \\
\text { Orientation }\end{array}$ & $\begin{array}{l}\text { Derajat kepedulian seseorang terhadap tugas dan } \\
\text { kewajibannya sehingga memiliki keinginan belajar } \\
\text { lebih baik atau melampaui standar }\end{array}$ & $\begin{array}{l}\text { Kemampuan untuk bertindak berdasarkan perundang- } \\
\text { undangan, nilai dan peraturan perusahaan }\end{array}$ & & & \\
\hline 14. & Integrity &
\end{tabular}

Keterangan:1: Sangat kurang, 2: Kurang, 3: Sedang, 4: Baik, 5: Baik Sekali

\section{Matriks metode pengumpulan data}

Metode tes yang digunakan dalam penelitian asesmen potential review ini dapat terlihat pada matriks tabel dibawah:

\section{PEMBAHASAN}

Tabel 2. Matriks metode pengambilan data

\begin{tabular}{|c|c|c|c|c|c|c|}
\hline \multirow[b]{2}{*}{ Kompetensi } & \multicolumn{6}{|c|}{ Metode Asesmen } \\
\hline & TIKI & Kraeplin & Papi Kostick & $\begin{array}{l}\text { Grafis } \\
\& \\
\text { Warteg }\end{array}$ & $\begin{array}{c}\text { Observasi } \\
\& \\
\text { Wawancara }\end{array}$ & LGD \\
\hline Strategic Thingking & $\checkmark$ & & $\checkmark$ & $\checkmark$ & $\checkmark$ & $\checkmark$ \\
\hline $\begin{array}{l}\text { Problem Solving \& } \\
\text { Decision Making }\end{array}$ & & & & $\checkmark$ & $\checkmark$ & $\checkmark$ \\
\hline CS Orientation & & $\checkmark$ & $\checkmark$ & & $\checkmark$ & $\checkmark$ \\
\hline Change Leadership & & & $\checkmark$ & & $\checkmark$ & $\checkmark$ \\
\hline Intrapreneurship & & & & & $\checkmark$ & $\checkmark$ \\
\hline Information Seeking & & & $\checkmark$ & & $\checkmark$ & $\checkmark$ \\
\hline $\begin{array}{l}\text { Port Planning \& } \\
\text { Operation }\end{array}$ & & & & & $\checkmark$ & $\checkmark$ \\
\hline Port Development & & & & & $\checkmark$ & $\checkmark$ \\
\hline Developing Other & & & & & $\checkmark$ & $\checkmark$ \\
\hline Computer Literacy & & & & & $\checkmark$ & $\checkmark$ \\
\hline Communication & & & & & $\checkmark$ & $\checkmark$ \\
\hline $\begin{array}{l}\text { English } \\
\text { Communication }\end{array}$ & & & & & $\checkmark$ & $\checkmark$ \\
\hline $\begin{array}{l}\text { Achievement } \\
\text { Orientation }\end{array}$ & & & $\checkmark$ & & $\checkmark$ & $\checkmark$ \\
\hline Integrity & & & $\checkmark$ & & $\checkmark$ & $\checkmark$ \\
\hline
\end{tabular}

\section{Dinamika Psikologi}

Berdasarkan rangkaian asesmen yang dilakukan kepada Sdri.Y, menunjukkan sejumlah aspek kompetensi yang ditemukan. Secara rinci, terdapat 10 kompetensi yang memenuhi standar, 3 kompetensi pada kategori diatas standar, dan 1 kompetensi tidak teridentifikasi. Dibawah ini akan menjelaskan secara spesifiki mengenai dinamika psikologis dari Sdri.Y Dari 14 kompetensi dibagi menjadi 3 cluster yang terdiri atas kemampuan berpikir, cara kerja, dan kepribadian.

Pada cluster kepribadian, termasuk di dalamnya adalah sebuah kemampuan dan dorongan untuk memberikan hasil kerja terbaik dan membuat berbagai perubahan untuk kemajuan perusahaan, Sdri.Y menunjukkan bahwa ia mampu melaksanakan tugas-tugas dan pekerjaannya dengan baik sesuai dengan standar kinerja individu, shingga orientasi dalam pencapaian pribadinya adalah standar kinerja yang telah di tetapkan pada posisinya. Hal lain pada cluster ini juga membahas tentang sejumlah tindakan dalam menyelesaikan pekerjaan 
yang tidak melanggar pada aturan, nilai, dan perundang-undangan mengingat PT.X merupakan sebuah perusahaan pelayanan yang erat kaitannya dengan regulasi pemerintah. Sdri.Y menunjukkan bahwa ia mampu melakukan analisa sederhana dan mengidentifikasi peraturan internal kemudian dikaitkan pada tugas-tugasnya, ia juga memahami bahwa mana aturan yang masih memerlukan optimalisasi untuk mendorong percepatan kinerja perusahaan dan tentu orientasinya juga adalah menambah profit perusahaan.

Cluster selanjutnya adalah pada kemampuan berpikir, pada cluster ini termasuk di dalamnya tentang kemampuan untuk mengembangkan berbagai aspek dan langkah-langkah yang diambil perusahaan untuk menyelaraskannya dengan sasaran organisasi dan secara umum mengembangkan strategi perusahaan, selain itu juga kemampuan untuk menganalisa dan memilah sejumlah peristiwa dengan menggunakan informasi dan pendekatan untuk mengambil keputusan yang tepat. Sdri.Y menunjukkan bahwa ia berada satu tingkat dari standar kompetensi pada posisinya yang artinya ia mampu membuat rencana kerja dengan mengidentifikasi masalah dan prinsip dasar proses perencanaan bisnis perusahaan serta memperimbangkan kondisi pada unitnya untuk menyelaraskan kemampuan dan sasaran yang ingin dicapai, selain itu hal yang menonjol lainnya adalah ia mampu mengambil sebuah keputusan dengan mempertimbangkan secara komprehensif atau menyeluruh mulai dari dampak resiko dan keuntungan jangka panjang atau jangka pendek, hal ini memang juga didukung karena dengan latar belakang pendidikan teknik dan manajemen sehingga menunjangnya dalam mengambil keputusan yang tepat pada posisinya atau secara umum.

Pada cluster selanjutnya adalah cara kerja, hal ini di dalamnya memiliki banyak poin dibandingkan cluster sebelumnya yaitu membahas tentang kemampuan untuk memberikan pelayanan dan meningkatkan pelayan karena berhubung proses bisnis PT.X dibidang port services, kemudian kemampuan untuk memberikan dorongan, melibatkan dan mempengaruhi bawahan untuk melakukan perubahan, kemampuan untuk mengidentifikasi sumber daya perusahaan agar meningkat performa perusahaan, kemampuan untuk menggali informasi secara menyeluruh dan lengkap, kemampuan untuk melakukan perencanaan pengembangan dan pengoperasian fasilitas pelabuhan dan penunjang yang mencakup kawasan industri, memiliki keahlian dalam pengembangan pelabuhan, serta beberapa kemampuan lain yang cukup mendasar adalah keahlian dalam penggunaan sejumlah software komputer dan kemampuan berbahasa inggris serta komuniskasi secara umum.

Secara umum berdasarkan hasil asesmen pada cluster ini, Sdri.Y menunjukkan bahwa dalam hal pelayanan kepada pengguna jasa, ia dapat memberikan respon yang cepat terhadap kebutuhan pengguna jasa serta mengidentifikasi kebutuhan yang diinginkan. Hal ini juga didukung oleh kemampuannya dalam mengumpulkan informasi dari sejumlah sumber sehingga ia mendapatkan informasi yang menyeluruh dan lengkap, selain itu penggunaan media yang efektif juga dilakukannya untuk menyampaikan informasi secara jelas, hal yang menonjol pada Sdri. Y adalah ia menguasai dasar-dasar dua kemampuan bahasa lain yaitu inggris dan arab yang tentu akan menunjang komunikasi dan interaksinya jika berhubungan dengan pengguna jasa asing atau melakukan koordinasi dengan pihak perusahaan asing. Selain itu, kemampuannya dalam menggunakan sejumlah program komputer seperti MS. Wor, MS, excel, MS. Power poin, dan kemampuan spesifik dalam membuat proyeksi virtual yang didapatkannya dengan latar pendidikan teknik cukup menunjangnya dalam meningkatkan kinerja di posisinya.

Sdri.Y juga menunjukkan bahwa ia mampu menyusun langkah-langkah peningkatan efisiensi operasional atau pendapatan baik dalam hal pemeliharaan fasilitas dan penunjang maupun penambahan, kemudian hal tersebut menjadi landasannya untuk mengusulkan hal-hal apa saja yang masih kurang optimal berdasarkan analisis sederhana yang dilakukan. Beberapa kemampuan lain yang yang menunjang hal ini adalah ia mampu mengatasi kendala-kendala yang terjadi diluar perencanaan dengan menerapkan pengetahuan teknis yang dimilki dengan latar belakang pendidikan teknik dan manajemen serta pengalamannya di perusahaan PT.X ini lebih kurang 17 tahun. Dalam kaitannya dengan perencanaan dan pengoperasian pelabuhan, ia 
dapat menyusun kajian sederhana tentang kelayakan proyek ataupun secara umum melakukan konsultasi kepada pihak-pihak terkait seperti pihak konsultan maupun atasan untuk mempertimbangkan segala aspek dalam perencanaan pengembangan atau pemeliharaan. Adapun yang cukup menonjol pada kompetensi Sdri.Y adalah berada satu tingkat dari standar kompetensi pada posisinya yang menunjukkan ia mampu mengidentifikasi area mana yang membutuhkan perubahan dan menyusun rencana perubahan yang selaras dengan program perubahan perusahaan.

Dari rangkaian asesmen yang dilakukan dengan hasil asesmen yang telah dipaparkan diatas, terdapat satu area kompetensi yang yang memerlukan adanya pengembangan. Mengingat bahwa keperluan potential review ini adalah untuk memotret kompetensi pegawai pada posisi Asisten Senior Manajer (ASM). Secara keseluruhan hasil kompetensi Sdri.Y cukup baik dibuktikan dengan level kompetensi yang dimiliki telah sesuai standar bahkan ada yang diatas standar, namun pada kompetensi developing other berada dibawah standar yaitu level 2 dari yang standarnya level 3, sehingga yang menjadi fokus dalam pengembangan kedepannya adalah untuk terus meningkatkan kompetensi Sdri.Y agar menjadi pegawai yang potensial, dengan meningkatkan kompetensi developing other.

Hal ini menjadi penting karena posisi Sdri.Y pun telah berada pada level struktural yang menuntut untuk memahami kondisi para pegawai yang ada di bawahnya, terutama dalam pemanfaatan SDM-SDM yang unggul untuk mendukung pencapaian kinerja perusahaan, sehingga perlu diajarkan bagaimana untuk menjadi seorang konselor sehingga ia bisa mengidentifikasi para bawahannya dan membangun serta mendorong para bawahannya untuk meningkatkan kinerja dan kompetensinya sebagai bentuk dukungan dalam program perusahaan untuk meningkatkan kompetensi pegawai dalam lingkup perusahaan. Ini akan dilakukan melalui proses pengajaran sederhana kepada Sdri. Y

\section{Umpan Balik}

Peneliti merekomendasikan untuk melakukan pelatihan atau pengajaran kepada Sdri.Y tentang bagaimana proses menggunakan konseling individu, dengan begitu diharapkan Sdri.Y dapat secara mandiri melakukannya untuk mengembangkan para bawahannya. Reber dan Reber (2010) memaparkan bahwa konseling merupakan istilah umum untuk memayungi sejumlah proses seperti tanya jawab, pengetesan, tuntunan, nasihat, dan semacamnya yang dirancang untuk membantu individu menyelesaikan masalah, merencanakan masa depan, ataupun hal serupa lainnya. Dalam perspektif etika, maka Himpunan Psikologi Indonesia (HIMPSI, 2010; 118) menjelaskan bahwa konseling adalah kegiatan yang dilakukan untuk membantu mengatasi masalah psikologis yang berfokus pada aktivitas preventif atau pencegahan dan pengembangan potensi positif yang dimiliki subjek dalam artian bawahan dari Sdri.Y dengan menggunakan prosedur berdasarkan teori yang relevan.

Konseling dipilih sebagai sebuah materi yang diajarkan pada Sdri.Y karena berdasar pada penjelasan Cummings dan Worley (2005) yang memaparkan bahwa konseling merupakan penciptaan hubungan yang memungkinkan subjek untuk merasakan, memahami, dan bertindak atas proses peristiwa tertentu. Sebuah pendekatan yang membantu orang-orang dan kelompok untuk membantu diri mereka sendiri. Himpunan Psikologi Indonesia (2010) juga menjelaskan bahwa konseling dapat dilakukan untuk menyelesaikan masalah pendidikan, perkembangan manusia ataupun pekerjaan baik secara individual maupun kelompok.

\section{Tahapan-Tahapan Konseling kepada bawahan}

Konseling individual akan dilakukan dengan berpedoman pada empat tahapan konseling menurut Cormier dan Hackey (dalam Gibson dan Mitchell, 1995) yaitu:

\section{Membangun Hubungan}

Tahapan ini berfokus pada membangun hubungan selama konselng dengan bawahan. Dalam membangun hubungan perlu memperhatikan asas kerahasiaan, kesukarelaan, keterbukaan dan kegiatan.

\section{Identifikasi Masalah}

Tahapan ini berfokus pada memperjelas dan mengidentifikasi masalah dan 
mengeksplorasi masalah bawahan secara lebih dalam. Eksplorasi tersebut bertujuan agar bawahan mempunyai perspektif dan alternatif baru dalam penyelesaian masalah yang dialami.

Perencanaan Pemecahan Masalah

Tahap ini berfokus pada penilaian kembali, konselor dan bawahan meninjau kembali permasalahan yang dihadapi oleh bawahan kemudian menyusun rencana tindakan yang akan dilakukan berdasarkan kesepakatan yang telah dibangun dari proses konseling sebelumnya.

\section{Aplikasi Solusi dan Pengakhiran}

Pada tahap ini berfokus pada pembuatan kesimpulan mengenai hasil proses konseling yang telah dilakukan oleh konselor dari bawahan, mengevaluasi jalannya proses konseling. Tahap ini ditandai dengan beberapa hal yaitu menurunnya kecemasan bawahan, perubahan perilaku bawahan kearah yang lebih positif dan sehat. Pemahaman baru dari bawahan terkait dengan masalah yang dihadapi dan adanya hidup masa depan yang jelas.

\section{Tujuan Konseling kepada bawahan}

Tujuan dari konseling yang dilakukan yakni untuk membantu bawahan dalam meningkatkan kemampuan yang dimilikinya sehingga bawhaan akan merasa lebih mampu menjalankan peran dan fungsinya pada unit kerja

\section{Sasaran Konseling kepada bawahan}

Bawahan dapat memahami dirinya sendiri baik kelebihan maupun area yang perlu dikembangkan.

\section{Durasi Konseling}

Pelaksanaan konseling akan dilakukan selama 75 menit dengan rincian sebagai berikut:
a. Tahap membangun rapport
: 5 menit
b. Tahap identifikasi masalah dan eksplorasi
: 20 menit
c. Tahap perencanaan pemecahan masalah
: 30 menit
d. Tahap aplikasi solusi dan pengakhiran
: 15 menit

\section{KESIMPULAN}

Dari keseluruhan rangkaian asesmen yang dilakukan kepada Sdri.Y, menunjukkan bahwa, terdapat 10 kompetensi yang memenuhi standar, 3 kompetensi pada kategori diatas standar, dan 1 kompetensi dibawah standar. Artinya, secara umum Sdri.Y memenuhi standar pada posisinya saat ini, hanya diperlukan pengembangan lanjutan mengenai kompetensi yang dibawah standar.Peneliti memberikan rekomendasi untuk melakukan pelatihan atau pengajaran singkat kepada Sdri.Y untuk menjadi konselor agar dapat mengembangkan kompetensi developing other yang lebih implementatif. Hal ini dirasa perlu karena posisi Sdri.Y ada lah jabatan struktural yang mesti memahami dan mengidentifikasi serta mengembangkan kompetensi bawahannya

\section{Referensi}

Boulter, N., Dalziel, M., \& Hill, J. 2003. Manusia dan Kompetensi: Panduan Praktis untuk Keunggulan Bersaing. Terjemahan oleh Bern Hidayat, PT. Gramedia. Jakarta

Boyatziz, R.E. 1982. The Competent Manager: A Model for Effective Perfomance. A Wiley-Interscience Publications. Canada.

Cummings, G, \& Worley, G. 2008. Organizational Development \& Change. Cengage Learning. United State of America

Gibson, R.L. \& Mitchell, M. H. 1995. Introduction to Guidance. Macmillan Publisher. New York

HIMPSI. 2010. Kode Etik Psikologi Indonesia. Cetakan Pertama, Pengurus Pusat HIMPSI. Jakarta.

Munandar, U. 2003. Pengembangan Kreativitas Anak Berbakat. Gramedia Pustaka Utama. Jakarta. 
Miller, L.A., \& Lovler, R.L. 2016. Foundation of Psychological Testing: a Pracrical Approach. SAGE Publications, Inc. United State of America

Nuraeni. 2012. Tes Inteligensi dan Tes Bakat. UM Purwokerto Press. Yogyakarta.

Raco, J.R. 2010. Metode Penelitian Kualitatif: Jenis, Karakteristik dan Keunggulannya. PT. Grasindo. Jakarta.

Reber, A. \& Reber, E. 2010. Kamus Psikologi: Terjemahan oleh Yudi Santoso. Pustaka pelajar. Yogyakarta.

Rumiani, dkk. 2014. Informasi Tes Psikologi: Panduan untuk Tester Seri 1. Smartania Publishing. Yogyakarta.

Yukl, G. 2015. Leadership In Organization 